\title{
The Adaptation of Contents for the Creation of Foreign Language Learning Exams for Mobile Devices
}

\author{
doi:10.3991/ijim.v3s1.1008 \\ J.L. Gimenez, T. Magal Royo. Fco. Garde Calvo and S. Prefasi Gomar \\ Polytechnic University of Valencia, Valencia. Spain.
}

\begin{abstract}
This article describes the process of adaptation of online digital contents for the realization of foreign language learning tests through mobile devices.
\end{abstract}

Taking into account the need detected in relation to the quick development of mobile technologies, the development and adaptation of existing online exams for mobile devices will be studied. We will do that by considering the possible navigation limits when using multiplatforms, and the aspects related to the formal and technical conditions which the audiovisual contents shown by the device must fulfil.

The existing online language learning tests can be adapted to mobile devices through the programming XHTML language. But, the limitations of navigability in relation to contents and the handling of interaction devices available for users to do the tests must also be considered.

Index Terms-m-learning, mobile applications, language learning, user-oriented interfaces, Online English Assessment Tests .

\section{INTRODUCTION}

The studies carried out about students' perception when using m-learning indicate that learning through mobile devices is widely accepted by the university student community (Seibu Mary Jacob and Biju Isaac, 2008) [1]. Students seem to be very interested in acceding to contents through portable computers, Palms, mobile phones and PDAs as they permit a quick access to contents and information anytime and anywhere.

Nevertheless, when they accede to information through PDA or mobile phones, the reduced size of the screens makes the process difficult (Avgeriou. P, 2003). It affects the students' capacity when they have to introduce a large text in a mobile device, when they take notes or when they have to answer to some questions when practicing.

If we consider this fact, we can say that multiple choice questions are the most appropriate to be implemented by a mobile device, as the process of interaction with the keyboard, which is the most commonly used system, could be quick and easy for the student. This evaluating system through tests also constitutes an active methodology which permits the student to have an autonomous, active and responsible role in the learning process (Álvarez y Schatcher, 2006) [3]
Nowadays, online exams addressed to the foreign language learning and testing process are generally focused on listening, the structural aspects, writing, and reading. An example is the English as a foreign language test TOEFL iBT, an online exam in which reading, listening, speaking and writing in English are tested in a telematic way. (TOEFL) [4].

The article tries to show the viability of the implementation of the existing online tests for foreign language learning through mobile devices, taking into account both their technical and functional limitations.

\section{TECHNICAL CONSIDERATIONS}

According to the report edited by the Fondo Investimenti per la Ricerca di Base, FIRB in 2004 about technical limitations of accessibility and use of mobile phones, there are some aspects which must be considered in relation to the adaptation of contents. They refer to contents which could directly affect not only to the implementation of language online tests but also the handling of related contents. In that report, there are some guidelines that we want to consider in this article through a table. It shows the technologic limitation and the way in which it can affect the interaction/interface with the user and the access to contents by using a mobile phone.

Web technology for the creation of digital contents for mobile devices considers the standard XHTML, developed by the World-Wide Web Consortium [5], International consortium which produces some standards for the World Wide Web. It is a language of marks for the creation of all kinds of contents. It does not matter whether it is addressed to Internet or to desk computers or to the field of mobile devices. (Developers' Home, 2008)[6].

The Mobile Web Initiative (MWI)[7] of W3C has published several recommendations for the generation of contents in mobile devices. It is shown in the document Mobile Web Best Practices 1.0 [8], created thanks to the contribution of the developers of contents for mobile devices and leader industrial organizations.

This document specifies the best practices for the delivery of web contents through mobile devices trying to improve the user's experience when connecting with the web from mobile devices.

When we adapt contents to mobile devices in which the student-platform-evaluator play a very important role, it is convenient to develop an intuitive and easy handling and learning interface. ( See table 1) 
TABLE I.

TECHNOLOGIC LIMITATIONS IN RELATION TO NAVIGABILITY AND CONTENTS

\begin{tabular}{|c|c|c|}
\hline $\begin{array}{l}\text { Technologic } \\
\text { limitation }\end{array}$ & Interaction/interface & Contents \\
\hline $\begin{array}{l}\text { Reduced size of } \\
\text { the screen }\end{array}$ & $\begin{array}{l}\text { The space of the user's } \\
\text { interface gets limited. }\end{array}$ & $\begin{array}{l}\text { The length of letters } \\
\text { of the contents shown } \\
\text { on the screen gets } \\
\text { limited. }\end{array}$ \\
\hline $\begin{array}{l}\text { Limited mecha- } \\
\text { nisms for the } \\
\text { introduction of } \\
\text { data }\end{array}$ & $\begin{array}{l}\text { Use of minimized key- } \\
\text { boards with more than } \\
\text { one function per key. } \\
\text { Mechanisms based on } \\
\text { the use of tactile screens } \\
\text { for the selection of } \\
\text { functions. }\end{array}$ & $\begin{array}{l}\text { Users have to be very } \\
\text { attentive when intro- } \\
\text { ducing data by typ- } \\
\text { ing. Non-ergonomic } \\
\text { keyboards. Pointers } \\
\text { with very small selec- } \\
\text { tion areas. }\end{array}$ \\
\hline $\begin{array}{l}\text { Limited band- } \\
\text { width and cost }\end{array}$ & $\begin{array}{l}\text { Limitation of the ser- } \\
\text { vices offered by mobile } \\
\text { internet. }\end{array}$ & $\begin{array}{l}\text { Problems when } \\
\text { transmitting data and } \\
\text { contents. }\end{array}$ \\
\hline $\begin{array}{l}\text { Limited capacity } \\
\text { of the process } \\
\text { and less powerful } \\
\text { operative systems }\end{array}$ & $\begin{array}{l}\text { The capacity of their } \\
\text { applications also gets } \\
\text { limited. }\end{array}$ & $\begin{array}{l}\text { Some problems arise } \\
\text { when presenting the } \\
\text { interaction processes } \\
\text { with the contents. }\end{array}$ \\
\hline $\begin{array}{l}\text { Limited capacity } \\
\text { of their batteries. }\end{array}$ & $\begin{array}{l}\text { Limited autonomy of } \\
\text { the devices. When there } \\
\text { are more functions, the } \\
\text { consumption increases, } \\
\text { accelerating the dis- } \\
\text { charge of the batteries. }\end{array}$ & $\begin{array}{l}\text { The use of multitask } \\
\text { resources gets lim- } \\
\text { ited, limiting the } \\
\text { shared use of contents } \\
\text { too. }\end{array}$ \\
\hline $\begin{array}{l}\text { Slow transmis- } \\
\text { sion of data } \\
\text { online }\end{array}$ & $\begin{array}{l}\text { It delays the feedback } \\
\text { of the application when } \\
\text { it has to consult the } \\
\text { data. }\end{array}$ & $\begin{array}{l}\text { It reduces the amount } \\
\text { of data which can be } \\
\text { consulted. }\end{array}$ \\
\hline $\begin{array}{l}\text { Great heteroge- } \\
\text { neity of the op- } \\
\text { erative system } \\
\text { and physical } \\
\text { characteristics. }\end{array}$ & $\begin{array}{l}\text { Users must get adapted } \\
\text { to new ways of interac- } \\
\text { tion when they use a } \\
\text { new device. It implies a } \\
\text { new learning process. }\end{array}$ & $\begin{array}{l}\text { The user gets focused } \\
\text { on the interface in- } \\
\text { stead of on contents } \\
\text { learning. }\end{array}$ \\
\hline
\end{tabular}

We can easily get absentminded, our sight sense needs to get sharper and the degree of eye/hand coordination can vary enormously depending on the user.

It is necessary to know the content necessities that the user can assimilate, getting adapted to their environmental needs and limitations.

When these aspects are explored, it is clear that the interface design of a mobile device can result into a very different solution if compared with its desktop equivalent.

\section{EXAMS DEVELOPMENT AND ADAPTATION}

PAUER, the project to develop foreign language learning exams on-line, was created in web format by the Graphics Technologies Research Centre together with the Department of Applied Linguistics at the Polytechnic University of Valencia. This exam online consists of three modules: one of them evaluates the grammar skills, the second one evaluates writing and the last one evaluates the speaking capacity. This exam online is based on the scheme of the university entrance exams in Spain.

Each of them evaluates these skills in different ways. The written sections can consist of two different kinds of questions, basically two types: open and closed questions (Hipólito González, 2001)[9].
In the case of the first type, the student just has to select the correct answer from several alternatives. True or false, multiple choice and matching questions are examples of this. These questions are also known as closed questions.

In the second case, the students have to elaborate their own answers to the exam questions. Completing sentences, short answers, essay answers, opinion or justification answers in relation to the formulation are some examples. This type is known as open questions.

Another kind of evaluation requires the use of multimedia devices in order to test the students' foreign language knowledge, i.e. listening or speaking tests. The PAUER platform reported about the necessity of including oral tasks among the diagnosis tasks (García Laborda y Magal, 2007)[10]. Images and audio recordings would improve and facilitate the students' comprehension.

\section{THE CREATION OF OPTIMIZED CONTENTS FOR MOBILE PHONES.}

The use of textual and audiovisual contents in the case of a test or exercise adapted to foreign language mlearning environments gets focused on getting information about which the Basic methods of adaptation of contents to m-learning are. (Cameron Moll, 2008) [11] They are mostly focused on the aesthetical aspect and their most complete alternative is the valuation of aspects which are inherent to mobility, the context and the users's concrete necessities when using these mobile devices.

There are four basic methods for the adaptation of contents.

\section{A. Doing nothing.}

If contents are not modified, we have digital contents which are not adapted to the mobile device. That implies that the navigability which had been programmed for those contents is not viable now, as the resource code is not completely compatible.

In the case of the contents of a test or tests which are part of an online exam adapted to the mobile device without a strict control of the base structure, it could result into non-visible information, an uncontrolled fragmentation of the information, etc. This could directly affect to the navigability as it is necessary to programme beforehand the sequence of screens because of the technological limitations of the mobile devices, not paying attention to usability concepts.

\section{B. The modification of the design style and the reduction of the images.}

We have to recognise that most of the available devices support HTML [12] and WML [13]. These languages are based on the implicit hierarchy of marks to permit the interpretation of their content by these navigators. The adaptation of the design to the mobile devices implies that the design is synthesized and the images are reduced in order to optimize the file, even removing everything which is superfluous, in order to reduce to the minimum the style of the content.

The adaptation of the contents of the exams by using this methodology is attractive because of its easy application, but it is not very helpful in relation to its contextual relevance. Besides, the file size can be excessive, not because of the marks but the text content. It can be very tir- 
ing in its own. The result is often a page with a very long scroll bar which would make the application of mobile devices useless.

\section{Use of style sheets.}

The use of style sheets (CSS)[14] has been seen as the most favourable way for the adaptation to the mobile Web. This is because the CSS, together with the XHTML are part of the standard and are used in the case of internet for desktop computers and mobile devices. Just one URL address is necessary to accede to the contents.

Thought it seems that we have found the panacea in relation to the adaptation of the contents of exams to mobile devices, there is a series of objections that we must take into account.

Not all the current mobile devices support this kind of attributes, so they can be undetectable for some of them. Even in the case of devices which support them, the users' data can be excessive as the hidden content does not appear on the screen despite of being downloaded to the device.

But the most important part is that this approach does not make reference to the contextual value, the style sheets mainly refer to the aesthetic part instead of the context, and it also pays little attention to content which is really important for mobile navigation.

\section{Contextual adaptation to mobile devices.}

Finally, this last method pursues the adaptation by means of two concepts. The first one refers to how we can accede to the contents. In the case of the second one, context is the priority, the contents are prior to the aesthetic aspects, function is prior to form.

Following this method, the inner characteristics of mobile devices are taken into account, paying less attention to the characteristics of the desktop web. Following this adaptation of the foreign language learning contents, we get optimized pages which are more agile, which save a great amount of unnecessary data and offer a more pleasant and enriching experience.

\section{CONCLUSIONS}

Considering the possible methods of adaptation of the existing contents to the resources, we can say that in the case of foreign language learning exams, the technological limitations affect seriously the way in which contents are presented in mobile devices. The screen size gets reduced, there are limited mechanisms for the introduction of data, a limited process capacity, limited bandwidth, limited autonomy...

If we want to obtain a high degree of usability of the application for foreign language evaluation, the system must be adapted to the user's necessities. We would get an effective, efficient and satisfactory use in a specific context.Due to the singularity of this m-learning context, we must adapt contextually the contents to the mobile devices in order to take advantage of all the possibilities offered by this resource. There would be changes in the type of items by introducing closed questions or open questions consisting of matching and filling-in exercises.All those questions which are based on an indiscriminate use of the text would be removed, e.g. essay questions due to the limitations of the entry mechanisms. We could also adapt multimedia video and audio questions if we take into ac- count that this would reduce considerably the number of devices which are capable of offering these services.

\section{REFERENCES}

[1] Seibu Mary J., Biju I. "Mobile Technologies and its impact - an análisis in higher education context" iJIM -Volume 2, Issue $1, \mathrm{Pp}$ 17. January 2008

[2] Avgeriou.P Management Systems, Educational Technology \& Society. Vol. 6, No. 2, pp.11-24. (2003)

[3] Álvarez y Schatcher (2006). El teléfono móvil: una herramienta eficaz para el aprendizaje activo. Formatex. Current Developments in Technology-Assisted Education.

[4] ETS Official TOEFL Site. Sitio oficial de Test of English as a Foreign Language. http://www.ets.org/toefl. Date of access $12 / 09 / 08$.

[5] W3C World-Wide Web Consortium. http://www.w3c.es/Consorcio. Date of access 14/09/2008

[6] Developers' Home. September 28, 2008 http://mobilewebbook.com/shorty/46509. Date of access 14/09/2008

[7] Mobile Web Initiative más información sobre MWI http://www.w3.org/Mobile. Date of access 14/09/2008

[8] W3C. Mobile Web Best Practices 1.0 Basic Guidelines W3C Recommendation 29 July 2008 http://www.w3.org/TR/mobile-bp Date of access 14/09/2008

[9] González Zamora, Hipólito. Cartilla docente "La evaluación de los estudiantes en un proceso de aprendizaje activo", Pp 30-32, Universidad Icesi, 2001.

[10] García Laborda, J., Magal Royo, T. Diseño y validación de la plataforma PLEVALEX como respuesta a los retos de diseño de exámenes de lenguas para fines específicos, Ibérica, 14, Pp. 59-78. (2007)

[11] Cameron Moll. "Mobile Web Desing. A web standards approach for delivering content beyond the desktop". http://mobilewebbook.com. Date of access 12/09/08.

[12] HTML 4.01 Specification W3C Recommendation 24 December 1999 http://www.w3.org/TR/html4. Date of access 12/09/08.

[13] Ted Wugofski. Towards Convergence of WML, XHTML, and other W3C Technologies. Last updated: 31st May 2000. http://www.w3.org/2000/09/Papers/Wugofski.html. Date of access $12 / 09 / 08$.

[14] World Wide web consortium. Guía Breve de CSS. http://www.w3c.es/divulgacion/guiasbreves/HojasEstilo. Date of access 1 12/09/08.

\section{AUTHORS}

Gimenez López, Jl. is with Polytechnic University of Valencia (Valencia 46022. Spain) and associated researcher with the Graphics Technologies Research Centre, Spain (e-mail: jogilo@upvnet.upv.es).

Magal-Royo, T, PhD., is with Polytechnic University of Valencia (Valencia 46022 Spain) as professor. and associated researcher with the Graphics Technologies Research Centre, Spain (e-mail: tmagal@degi.upv.es).

Garde Calvo, F. is with Polytechnic University of Valencia (Valencia 46022. Spain) and associated researcher with the Graphics Technologies Research Centre, Spain (e-mail:fragarca@upvnet.upv.es).

Prefasi Gomar, S. is with Polytechnic University of (Valencia Valencia 46022). Spain and associated researcher with the Graphics Technologies Research Centre, Spain (e-mail:salprego@upvnet.upv.es).

This work was supported by Science and Innovation Ministry under national program. HUM2007-66479-C02-02/FILO.

This article was modified from a presentation at the International Conference on Interactive Mobile and Computer Aided Learning (IMCL2009) in Amman, Jordan, April 2009. Submitted, October, 7, 2008. Published as resubmitted by the author(s) on July, 20, 2009. 